\title{
The impact of leadership on absorptive capacity: new insights from the UAE
}

Article

Accepted Version

Zadeh Rezaei, M., Haak-Saheem, W., Darwish, T. K. and Satwinder, S. (2020) The impact of leadership on absorptive capacity: new insights from the UAE. Canadian Journal of Administrative Sciences, 37 (4). pp. 448-458. ISSN 1936-4490 doi: https://doi.org/10.1002/cjas.1561 Available at https://centaur.reading.ac.uk/87461/

It is advisable to refer to the publisher's version if you intend to cite from the work. See Guidance on citing.

To link to this article DOI: http://dx.doi.org/10.1002/cjas.1561

Publisher: Wiley

All outputs in CentAUR are protected by Intellectual Property Rights law, including copyright law. Copyright and IPR is retained by the creators or other copyright holders. Terms and conditions for use of this material are defined in the End User Agreement.

\section{www.reading.ac.uk/centaur}

\section{CentAUR}

Central Archive at the University of Reading 
Reading's research outputs online 


\title{
The Impact of Leadership on Absorptive Capacity: New insights from the Middle East
}

\begin{abstract}
This paper investigates the impact of transformational and transactional leadership on the absorptive capacity of firms within an emerging market setting. Unlike some existing accounts from the Western world, the results indicate that both transformational and transactional leadership styles positively influence the learning processes of absorptive capacity. More specifically, the results indicate that transactional leadership style positively influences the exploratory and transformative learning processes, while the transformational leadership style positively affects the exploitative learning process. Given the unique institutional context under investigation, the uneven and loosely coupled institutional arrangements - a common feature of petroleum-growth regimes - reflect the need for leadership guidance. We draw out the implications for theory and practice.
\end{abstract}

Keywords: Transformational and transactional leadership, absorptive capacity, learning, institutions, UAE.

\section{Introduction}

Research recognises that emerging market firms have relatively underdeveloped absorptive capacity (Bilgili, Kedia, \& Bilgili, 2016; Darwish, Zeng, Zadeh \& Haak-Saheem, 2018). Yet scant attention has been paid to the conditions that constrain or facilitate firms' absorptive capacity (AC) development within the emerging market economies. In this article, we explore how different leadership styles influence firms' absorptive capacity in the context of the emerging economy of a Gulf petro-state. We suggest that leadership styles influence firms' ability to utilise external knowledge through three sequential learning processes: exploratory, transformative and exploitative (Lane, Koka, \& Pathak, 2006). Although there is a burgeoning body of literature on 
AC and how it can enhance organisational performance (Zahra \& George, 2002; Todorova \& Durisin, 2007; Volberda, Foss, \& Lyles, 2010), the role of intra-organisational factors remains relatively under-investigated (Flatten, Adams, \& Brettel, 2015; Vera \& Crossan, 2004). From this perspective, leadership constitutes a particularly important internal dimension (Nonaka \& Takeuchi, 1995; Darwish et al., 2018). Existing research indicates that leadership is the core of organisational activities that influences the development of organisational capabilities and learning processes (Aragón-Correa, García-Morales, \& Cordón-Pozo, 2007; Pablo, Reay, Dewald, \& Casebeer, 2007), and leadership is critical to the enabling and sustaining of capabilities such as absorptive capacity (Berson, Nemanich, Waldman, Galvin, \& Keller, 2006; Teece, 2007).

Building on the organisational learning perspective, we investigate how firms' learning strategies influence their preferences with respect to sources of new knowledge, and consequently the implications of these strategic choices for their absorptive capacity. More specifically, absorptive capacity through its learning processes (see, e.g., Lane et al., 2006; Easterby-Smith et al., 2008; Volberda et al., 2010) enables organisations to look for new knowledge outside their boundaries, acquire and assimilate that knowledge, and utilise it for commercial ends (Cohen \& Levinthal, 1990). In order to make the best of unstable external circumstances, and particularly when external knowledge bases are limited and difficult to access, absorptive capacity is vested with particular importance (c.f. Lane, Salk, \& Leyles, 2001); however, in turn, this is dependent on internal governance and leadership (Tsai, 2001; Lane, Koka, \& Pathak, 2006; Lewin, Massini, \& Peeters, 2011). In this study, we explore the interplay between leadership and absorptive capacity, and how this differs from existing research evidence compiled in more balanced economies, and we draw out the implications for theory and practice. Unlike firms in developed economies, firms in less mature markets depend to a greater extent on the external environment to acquire knowledge 
(Darwish et al., 2018). While the term 'emerging market firms' implies a uniform category of firms, existing research shows that emerging economies vary greatly with regard to their overall progress towards economic development (Hoskisson, Wright, Filatotchev, \& Peng, 2013). Accordingly, firms operating within emerging markets are presented with different opportunities and are exposed to diverse challenges in their local institutional environments (Haak-Saheem, Festing, \& Darwish, 2017). However, firms operating in less developed institutional settings are latecomers to the global marketplace, and in order to achieve competitive advantage they must not only upgrade existing capabilities through continual learning but also develop new competencies. This is particularly true for firms operating within the context of the Arab Gulf countries.

Like Bahrain, Kuwait, Oman, Qatar and Saudi Arabia, the UAE is a member of the Gulf Cooperation Council (GCC). In addition, it is a member of the Organization of Petroleum Exporting Countries (OPEC), and about 40 per cent of the country's gross domestic product is based directly on oil and gas output (World Bank, 2012). Since the discovery of oil in the UAE, the country has become a modern state with a high standard of living, rooted in Islamic-based societal structures; over the last few decades, the UAE has applied an economic developmental model that strongly emphasises market liberalism and economic openness, embracing globalisation while at the same time refraining from challenging the traditional neo-patrimonial leadership structure in the country (Haak-Saheem et al., 2017). The fast and rapid growth of oilrich countries has depended on the income generated from their oil and gas resources. However, since more attention is paid to the natural resources in countries such as the UAE, it started to diversify its economy and so ensure the sustainable development and growth. Accordingly, the creation of a knowledge-based economy is the ultimate goal of the government and knowledge is 
identified as a key driver of the competitive economy. In this view, AC is critical to the dynamic development of the UAE.

From the institutional perspective, the developmental state paradigm highlights the critical role of government intervention in the country's economy and focuses on the institutional and political bases for effective intervention (Hvidt, 2009). As indicated in the UAE Vision 2021, a major aim of the government is to guide and support the preparation of the workforce for the high-value, knowledge-driven economy. Attracting and retaining highly skilled employees and improving nationals' qualifications and their levels of motivation are of specific importance. Furthermore, the challenges of absorptive capacity in the UAE are special as the ratio of 'nationals' to 'expatriates' is among the most disproportionate in the world (Harry, 2007; Hvidt, 2009; Forstenlechner \& Mellahi, 2014). Less than $20 \%$ of Dubai's total population are local citizens, which indicates that nationals are in the minority (Hvidt, 2009). Al-Waqfi and Forstenlechner (2014) further argue that the situation is even more problematic in the private sector, where almost 99\% of employees are expatriates. Given the demographic factors, it is therefore important to firms to acquire external knowledge (e.g. from the highly skilled international workforce). Yet little insight has been offered into how firms in such an institutional environment approach this.

To tackle the lack of understanding on how companies can develop and use absorptive capacity in the emerging economy such as UAE, we investigate the effect of leadership on absorptive capacity. Leaders have an important role in developing absorptive capacity (Zahra and George, 2002; Sun and Anderson, 2012; Rezaei-Zadeh and Darwish, 2016). Most of studies conducted in the western context where their organisational environment and leadership are different from emerging economy countries in the Arabian Gulf, specifically when it comes to leadership. Given the historical importance of leadership in the Arab culture (Ref) 
For example, it is assumed that transformational leadership is less appropriate for the emerging economy, while transactional leadership is more relevant to organisational performance. Despite of this assumption, a recent study showed that both transformational and transactional leadership are relevant in the emerging economies. We suggest investigating the influence of transformational and transactional leadership on absorptive capacity in order to understand which leadership has impact on absorptive capacity in our research context.

The central aim of our study is to connect the theoretical link between different learning processes of absorptive capacity and leadership. While previous literature (e.g. Darwish et al., 2018) shows there is an underlying assumption concerning the role of different leadership styles in absorptive capacity and innovation, in this paper, we offer insights into how specific leadership styles, such as transformational and transactional leaders, facilitate and promote the development of stocks and flows of different learning processes of absorptive capacity.

Further this research seeks to enhance our understanding if and how firms in an emerging petrostate explore and transform external knowledge successfully. Lastly, we aim to contribute to the theoretical discussion on the multi-dimensional nature of absorptive capacity by examining the relationship between the different learning processes and the effects of transformational and transactional leadership.

In the remainder of the article, we first provide a review of the existing literature on the concept of absorptive capacity, differing learning strategies and the role of leadership. Next, we introduce the key factors of our conceptual model and develop our hypotheses. Then, we discuss our methodological approach and present our findings. Finally, we discuss the implications of our research for theory and practice. 


\section{Theoretical and Contextual Background}

The notion of absorptive capacity is considered to be one of the most important constructs to emerge in organisational research in recent decades (Lane et al., 2006). Cohen and Levinthal (1989) define absorptive capacity as the fundamental learning process: an organisation's ability to identify, assimilate and exploit knowledge from the external environment. In this view, developing and maintaining absorptive capacity is critical to firm's long-term competitiveness because it can reinforce, complement or refocus the knowledge base (Zahra \& George, 2002; Lane et al., 2006; Gebauer, Worch, \& Truffer, 2012). Within management research, absorptive capacity is referred to by a wide range of theories, of which a large number address the context of learning (Lane et al., 2001), innovation (Tsai, 2001) and the knowledge-based view of the firm (Zhao \& Anand, 2009). Moreover, Zahra and George (2002) divide absorptive capacity into potential and realised absorptive capacity. Potential absorptive capacity captures knowledge acquisition and assimilation, which refers to a firm's capacity to identify and exploit externally generated knowledge. Realised absorptive capacity refers to abilities to transform and exploit knowledge for commercial purposes. Both potential and realised absorptive capacity are cumulative and depend on past experiences. Accordingly, absorptive capacity is not static, but, rather, emerges through learning processes over time (Todorova \& Durisin, 2007).

In the present study, we deploy the conceptualisation of Lane et al. (2006), in which absorptive capacity is defined as the firm's ability to utilise external knowledge through three sequential learning processes: exploratory, transformative and exploitative. The separation is necessary to understand the distinct processes behind each element (Lane et al., 2006). The exploratory learning process of absorptive capacity refers to the acquisition of external knowledge. The exploitative learning process describes the firm's ability to apply acquired knowledge. The transformative 
learning process links the exploratory and exploitative learning processes (Zahra \& George, 2002; Gebauer et al., 2012).

It is suggested that developing absorptive capacity increases organizational performance (Cohen \& Levinthal, 1990; Zahra \& George, 2002; Todorova \& Durisin, 2007). Accordingly, we suggest that researching factors which facilitates developing absorptive capacity pave a way to increase organizational effectiveness. One of the main factors is leadership. There are extensive research showing that leadership facilitate absorptive capacity (Sun and Anderson, 2012; Rezaei-Zadeh \& Darwish 2016; Darwish et al., 2018). the behaviours and attitudes of leadership, known as leadership style, encourage the processes of acquiring, assimilating, transforming, and implementing external knowledge (Sun and Anderson, 2012).

Leadership style reflects the assumptions that managers make regarding their roles in an organisation (Aragón-Correa et al., 2007). As Burns (1978) argues, two distinct leadership styles can be defined. A transformational leadership style promotes employees' needs and aspirations to a higher level and motivates employees to perform beyond their expectations (Bass, 1995; Jung, 2001). Transformational leaders have four characteristics: idealised influence, inspirational motivation, intellectual stimulation and individualised consideration. Through idealised influence, leaders instil a sense of pride, respect and faith in their employees. Through inspirational motivation, leaders establish and guide employees towards a challenging organisational vision by motivating them to meet higher expectations. Intellectual stimulation allows leaders to challenge existing organisational processes to solve problems. With individualised consideration, leaders consider individual differences in order to increase their employees' abilities and skills. 
On the other hand, transactional leaders are those who clarify their expectations of their employees (Bass, 1999; Yukl, 1999). It is suggested that transactional leadership has two characteristics: contingent rewards and management by expectations (Avolio et al., 1999; Bass, 1999; Yukl, 1999). With contingent rewards, leaders clarify the tasks their employees need to accomplish in order to gain rewards. With management by expectation, leaders monitor task progress and correct employees' mistakes.

In comparing these two distinct leadership styles, research has delivered mixed results (Yammarino, Spangler, \& Bass, 1993). Some scholars contrast these two leadership styles by suggesting that a transformational leadership style is more strongly associated with organisational change (e.g., Dess \& Picken, 2000) and some aspects of learning such as development of employees' abilities (e.g., Barczak \& Wilemon, 1992) and allowing experimentation (Snell, 2001).

Furthermore, it is argued that transactional leaders inhibit learning among team members because of their individualistic characteristics (Aragón-Correa et al., 2007). On the one hand, some argue that effective leaders should perform both transformational and transactional leadership styles (e.g., Bass, 1985; Conger \& Kanungo, 1998); it is argued that the combination of both is of particular importance for effective management of knowledge and learning processes (Conger, 1999; Vera \& Crossan, 2004; Sun \& Anderson, 2012; Rezaei-Zadeh \& Darwish, 2016; Darwish et el., 2018). On the other hand, it is also held that using transformational leadership alone is associated with superior leadership performance (see Bass, 1990). In general, the existing literature emphasises the positive effect of both transformational and transactional leadership on organisational outcomes (Boal \& Hooijberg, 2001). In addition, the differing impacts of distinct leadership styles have also been proven to be context specific (Elenkov \& Manev, 2005). 
Lane and Lubatkin (1998) note that the institutional context impacts on the extent and relative importance of absorptive capacity. The notion that organisations are embedded in a wider institutional environment suggests that organisational practices are often either a direct reflection of or responses to rules and structures existing in their wider environment (Paauwe \& Boslie, 2003).

Despite being among the wealthiest nations, as is common with many petro states, the Gulf countries face severe shortages in indigenous human capital and remain over-reliant on foreign knowledge and skills (Al Waqfi \& Forstenlechner 2010, 2014; Ewers 2013; Haak-Saheem, Darwish, \& Al-Nasser, 2016). Unlike other fast-developing markets, the UAE began its growth trajectory without surplus labour and has relied on a significant scale on expatriates, both skilled and unskilled (Thorpe and Connell, 2013). Further, as mentioned earlier, the ratio of 'nationals' to 'expatriates' is among the most disproportionate in the world (see, e.g., Harry, 2007; Hvidt, 2009; Forstenlechner and Mellahi, 2011). According to Al-Waqfi and Forstenlechner (2014), the disparity is even more pronounced in the private sector, where almost $99 \%$ of employees are expatriates.

The government aims to reduce the reliance on the foreign workforce and has introduced localisation policies (Emiratisation) to increase the participation of the local population in the workforce. Emiratisation has been in place for decades, with the application of three core tenets: the first long-term target is diversifying the economy and reducing over-reliance on the capitalintensive hydrocarbons sector; the second is overhauling the education system in order to align education to market needs; and the third is implementing a range of labour market intervention measures, such as setting quotas and allocating jobs to be staffed solely by nationals, to reduce the reliance on international labour. However, progress has been slow and uneven (see Forstenlechner 
\& Rutledge, 2011). Previous research (Haak-Saheem \& Festing, 2018) highlights the steering role of the government to push the development of the country further. Hence, the government plays an important role in shaping firms' leadership practices. Empirical evidence (Haak-Saheem \& Festing, 2018) shows the powerful mechanisms of how the vison of the country is cascaded to the organizations. Because of the strong link between the government and businesses, leadership style is an important factors influencing the absorptive capcity of organizations.

\section{Conceptual Model and Hypothesis Development}

Influence of transformational leadership on the absorptive capacity learning processes

Some of the existing literature argues that leadership influences the development of absorptive capacity. For instance, it has been held that the cognitive structure of leaders affects absorptive capacity (see Mom et al., 2007). Similarly, Sun and Anderson (2010) suggest that individuals, specifically leaders, through intuition influence the exploratory learning process of absorptive capacity. As Lane et al. (2006) mention, the exploratory learning process of absorptive capacity enables organisations to value and acquire knowledge from the external environment. Employees utilise their intuition to search for external knowledge (Sun \& Anderson, 2010) and they explain and interpret their intuition together (Nonaka \& Takeuchi, 1995). Hence, the exploratory learning process of absorptive capacity includes individual and group level learning.

Then, the acquired knowledge is assimilated from group level to other organisational units through the transformative learning process of absorptive capacity (Sun \& Anderson, 2010). As Lane et al. (2006) state, organisations combine acquired knowledge with their existing knowledge through the transformative learning process of absorptive capacity by analysing, interpreting and understanding external knowledge. We suggest that individuals have a prime role in the 
exploratory and transformative learning processes of absorptive capacity. On the other hand, the exploitative learning process of absorptive capacity refers to institutionalising external knowledge in order to implement knowledge continually (Lane et al., 2006; Sun \& Anderson, 2010). Institutionalisation is defined as learning that facilitates an interactive process to change organisational processes, systems and structures (Crossan et al., 1999). Therefore, the exploitative learning process of absorptive capacity takes place at the organisational level.

Successful knowledge acquisition and assimilation rely on organisations' desire to change their flexibility levels and their employees' creativity levels (Cepeda-Carrion et al., 2012). By considering the importance of change for external knowledge acquisition and assimilation (Zahra \& George, 2002), individuals employing the exploratory and transformative learning processes of absorptive capacity are looking for new solutions to organisational problems. Transformational leaders' intellectual stimulation and individual consideration characteristics encourage employees to look for new solutions, be more creative in their thinking and more readily adopt new organisational practices (García-Morales et al., 2008). Transformational leaders influence employees' learning by acting as mentors, facilitators and trainers (Ulrich et al., 1993). Transformational leaders provide support for organisational members to create and use knowledge (Senge et al., 1994; Snell, 2001) and also promote collaboration and teamwork (Aragón-Correa et al., 2007), which are essential for knowledge assimilation. Hence:

Hypothesis 1: Transformational leadership style positively influences exploratory learning.

Hypothesis 2: Transformational leadership style positively influences transformative learning. 
Successful implementation of external knowledge, on the other hand, requires employees to be ordered and controlled and the context to be rendered stable (Cepeda-Carrion et al., 2012). Implementation of external knowledge occurs through reusing knowledge in the exploitative learning process of absorptive capacity (Lichtenthaler, 2009; Sun \& Anderson, 2010). Organisations develop routines to implement and exploit external knowledge continually (Zahra \& George, 2002). The development of routines allows organisations to perform tasks in a consistent fashion over time. Since the transformational leadership style is more strongly associated with change (Gardner \& Avolio, 1998; Lowe et al., 1996; Howell \& Avolio, 1993) and the exploitative learning process of absorptive capacity requires stability in organisational tasks, we therefore suggest the following:

Hypothesis 3: Transformational leadership negatively influences exploitative learning.

The influence of the transactional leadership style on the absorptive capacity learning processes

It is suggested that the transactional leadership style facilitates learning processes (Vera \& Crossan, 2004). Unlike transformational leadership style, this leadership style prohibits experimentation (Rosing et al., 2011) and encourages the type of learning that promotes existing organisational activities and processes (Vera \& Crossan, 2004). Successful exploratory and transformative learning requires some degree of change (Zahra \& George, 2002). Moreover, by giving freedom to their employees leaders enhance group-level learning - that is, transformative learning (McGrath, 2001). Because transactional leadership style is less strongly associated with change and freedom for experimentation, we thus propose the following: 
Hypothesis 4: Transactional leadership negatively influences the exploratory learning process.

Hypothesis 5: Transactional leadership negatively influences the transformative learning process.

It is held that the transactional leadership style facilitates exploitative learning (see Sun \& Anderson, 2012). It is suggested that transactional leaders' behaviours encourage top-down decision-making, developing standard procedures for producing products and services (AragónCorrea et al., 2007). Developing routines helps organisations to establish standard procedures, which ensures organisations' activities, procedures and processes are performed in a predetermined way. Transactional leaders clarify tasks to their employees by developing an exchange relationship with them and take corrective action when necessarily (Bass, 1999). Therefore, we suggest the following:

Hypothesis 6: Transactional leadership positively influences exploitative learning.

\section{Methodology}

Sample and Procedures:

Data for this study comes from a questionnaire administered on managers of a randomly selected sample from different sectors (Education, Banking; Healthcare; Hospitality; Consultancy and others) in the UAE. Having gained prior corporate approval via inter-organisational mailing systems, the questionnaire employed was administered. Potential respondents were assured that participation was entirely voluntary and confidentially. Completed questionnaires were returned via a sealed envelope to a secured drop-off box for collection by the researchers only. The survey 
that was conducted over a period of 11 months had four sections in it: section I included questions on controls--gender, age group, education, experience, year the company was established and the total number of employees. Section II had eighteen questions on Likert scale addressed to managers in their role in searching, acquiring, assimilating, and using knowledge from other organisations. Section III had twenty five questions drafted to elicit characteristics of a firm's capacity to absorb new knowledge from other organisations (exploratory learning) ability to assimilate and transform acquired knowledge (transformative and exploitative learning process). Section IV was addressed to elicit information on understanding the speed of innovation introductions in their respective sectors. Questionnaires with $20 \%+$ missing responses were not considered. The final sample size yielded 986 usable answers generated from 1,500 distributed questionnaires, making a response rate of $65.7 \%$. About $2 / 3^{\text {rd }}$ of respondents were male $(63 \%)$, with the largest age group falling between 30 and 39 years of age (36\%). Detailed sample characteristics are shown in appendix A.

\section{Measures:}

We implemented the measurement items which were developed and tested in previous studies. For our dependent variables, we adopted the scales which have been developed by Lichtenthaler (2009) to measure the exploratory, transformative and exploitative learning processes. All questions were measured using a 5-point Likert scale. Our independent variables are leadership styles. We combined Podsakoff et al. (1996) and MLQ (Form 5X) (Bass and Avolio, 1995) to measure our predictors. These two scales have been well-established and used by a number of researchers (see, for example, García-Morales et al., 2008; Gumusluoğlu and Ilsev, 2009). Questions were also measured using a 5-point Likert scale. 


\section{Data Analysis}

Scale validity and reliability:

In the first stage of data analysis, one-dimension confirmatory factor analysis (CFA) was used. CFA is used to determine whether the number of factors (dimensions) and the loadings of measured items on them conform to what is expected on the basis of the proposed model (see Kim \& Mueller, 1978). Factor loadings below .40 were removed from the CFA Model. Further to using CFA to fit the results to one factor for our model, a Principal Components Analysis (PCA) with a Varimax rotation was carried out. The total variance explained for the overall model is $.44 \%$. This would also indicate acceptable construct validity. The reliability coefficient Cronbach's alpha for data consistency in the scales ranged between 0.63 (ELVP) and 0.80 (TFL) (see Table 1).

\section{INSERT TABLE 1 HERE}

\section{Model testing:}

The research model was tested using a linear structural equation modelling (SEM) with latent variables as this approach is well-suited to highly complex predictive models (Jöreskog, 1973). SEM is appropriate when theoretically derived paths amongst multiple exogenous and endogenous variables are estimated (Bollen, 1990; Byrne, 2013). In order to minimise the ratio of parameters to observations in estimating the model, scale values for each variable were calculated and corrected for random measurement error. In an effort to adjust for measurement error in the scale 
values, the error variance was set equal to the variance of the scale value multiplied by 1.0 minus the reliability (Jöreskog \& Sörbom, 1989). SEM has several strengths, which make it appropriate for this study, including its ability to handle both reflective and formative constructs.

\section{Results}

Table 2 provides the descriptive statistics and correlations for all variables. A brief analysis of the correlation matrix shows support for some of the stated hypotheses. In an effort to estimate the strength of the relationships between the suggested model variables, correlation analysis was performed. The mean, standard deviation and the correlation coefficient of all factors in the proposed model have been computed and tabulated in Table 2 .

\section{INSERT TABLE 2 HERE}

Structural equation modelling of data:

Hair, Anderson, Tatham and William (2006) and Hu and Bentler (1999) claim that a general set of criteria enables an evaluation of whether models are characterised by an acceptable fit. SEM analyses were performed using a covariance matrix as input to the Analysis of Moment Structure software (Arbuckle \& Wothke, 2003) using maximum likelihood estimation. The missing data were replaced through the use of the expectation maximisation (EM) approach prior to analysis. Moreover, for evaluating the model, residual means squared error (RMSEA), standardised root mean square residual (SRMR), normed fit index (NFI), comparative fit index (CFI) and goodness of fit index (GFI) values were taken into consideration, noting that a fit index value of more than 
0.90 and a means squared error of less than 0.08 would indicate a close fit of the model. The fit of the measurement model was acceptable (see Table 3), with a significant chi-square $=370.234, \mathrm{P}<$ $0.000 ; \mathrm{SRMR}=.0395 ; \mathrm{GFI}=.957 ; \mathrm{NFI}=.925 ; \mathrm{CFI}=.946$ and $\mathrm{RMSEA}=.048)$.

\section{INSERT TABLE 3 HERE}

Figure 1 shows the significant parameter estimates for the structural equation model. Surprisingly, there are significant positive effects identifiable for all of the tested hypotheses. As the results indicate, $\mathrm{H} 1$ and $\mathrm{H} 2$ are positively and strongly supported in that the estimate of the relationship between transformational leadership and both learning processes, exploratory $(\beta=.40, \mathrm{P}=0.000)$, and transformative $(\beta=.43, \mathrm{P}=0.000)$. Furthermore, $\mathrm{H} 3$ is rejected as transformational leadership is positively related to exploitative learning process $(\beta=.35, \mathrm{P}=0.000)$. With regards to transactional leadership, unlike what have predicted, $\mathrm{H} 4$ and $\mathrm{H} 5$ are both rejected as the predictor is positively related to both learning processes, exploratory $(\beta=.29, \mathrm{P}=0.000)$, and transformative $(\beta=.29, \mathrm{P}=0.000)$. Finally, the results indicate that $\mathrm{H} 6$ is supported as transactional leadership is positively related to exploitative learning process $(\beta=.32, \mathrm{P}=0.000)$. We discuss these results further in the discussion section.

\section{INSERT FIGURE 1 HERE}

\section{Further tests:}


The findings may reflect potential exogenous factors stemming from the diversity of the sample; therefore, in order to assess our findings, we conducted a multigroup analysis on the model (see Floh and Treiblemair, 2006). We particularly attempt to test whether or not the gender of the employee may have an impact in relationship between leadership style and learning processes. Behavioural researcher proposes several strategies to discern disparities related to behavioural differences of working female and male adults in organisations. Generally speaking, gender differences are mainly associated with either culture value systems (Hofstede, 1991) or personal attributes (Eagly, 1992; Malach-Pines and Kaspi-Baruch, 2008). However, Eagly, Wood and Diekman (2000) outline that males and females show different social behaviours owing to different societal and cultural expectations for the two genders. Social role theory proposes that all types of women's and men's social behaviour can be framed within the two extremes of a continuum: males are agentic and females are communal. Whitoak et al. (2006) argue that the Arab culture has a significant impact on behavioural differences between males and females; thus, in an effort to capture any potential difference, the sample was divided into two groups. Hence, we reran the model with this subsample and repeated the procedure to test whether or not there would be any significant changes. None of this further analysis resulted in any significant changes in the findings.

\section{Discussion and Conclusions}

The main purpose of this paper was to investigate the impact of leadership styles, namely transformational and transactional, on the learning processes of absorptive capacity in a Middle Eastern emerging market. Although the existing literature (see, e.g., García-Morales et al. 2008; Sun \& Anderson, 2012) indicates a positive relationship between transformational leadership and 
the learning processes of AC, the present results, surprisingly, indicate that both transformational and transactional leadership styles positively influence the learning processes of absorptive capacity More specifically, the results indicate that the transactional leadership style positively influences the exploratory and transformative learning processes, while the transformational leadership style positively affects the exploitative learning process.

Given our institutional context, leadership is an important factor influencing organisational practices and decisions. The uneven and loosely coupled institutional arrangements - a common feature of petroleum-growth regimes - reflect the need for leadership guidance. Moreover, transformational and transactional leadership is critical to guide and support learning processes in organisations in such an institutional environment. Furthermore, leadership plays an important role in directing the efforts of a highly diverse workforce towards the common goal to overcome the dilemma of relying on non-replenishable resources.

We found surprising results regarding the relationship between transactional leadership and the processes of absorptive capacity, particularly in relation to exploratory and transformative learning. This could be explained by the differences in the degree of change associated with absorptive capacity. Todorova and Durisin (2007) suggest two types of change associated with absorptive capcity: there is less divergence from the organisational knowledge structure when change is associated with knowledge assimilation; and there are some changes that require divergence from the existing organisational knowledge structure. It is suggested that the transactional leadership style is more effective when the organisational change is not groundbreaking and it requires some degree of stability (Vera \& Crossan, 2004). If the assimilation of knowledge does not involve a breakthrough change, transactional leadership can have a positive influence on the exploratory and transformative learning processes. On the other hand, when the 
change is radical, a transformational leadership style from top managers encourages their middle managers to stabilise the continual implementation of external knowledge and adapt to changes more effectively. This is because the transformational leadership style is more effective when the changes are radical (Vera \& Crossan, 2004).

This study also provided some important insights for managers working across all sectors within the UAE and also in comparable markets. Although managers should adapt to environmental change, whether or not they decide to impose radical or incremental change in organisations depends on their cognition. Prior work has suggested that managers should perform contradictory behaviours to improve absorptive capacity learning processes. For example, Cepeda-Carrion et al. (2012) mention that, while managers promote creativity and freedom to their employees in the early stages of absorptive capacity, the effectiveness of absorptive capacity processes also requires control. Therefore, managers should adopt a contingency approach in order to manage the learning processes of absorptive capacity effectively.

This study contributes to the growing interest in absorptive ca studies. While both transformational and transactional leadership styles have a positive influence on the learning processes of absorptive capacity, our results suggest that the influence of leadership styles differs with environment. Hence, different institutional arrangements could have different implications when it comes to the most effective leadership style. As suggested by Sun and Anderson (2012), when the environment is stable, the transactional leadership style facilitates the learning processes of absorptive capacity . Hence, the effectiveness of leadership styles is very much related to the degree of organisational change. Transformational leadership leads to more effective management of the learning processes when organisations impose radical or breakthrough change. On the other hand, transactional 
leadership is more effective when the organisational change is incremental. We therefore suggest that the degree of change influences the effectiveness of different leadership styles on absorptive capacity . Further, while existing studies encourage best practice for managing absorptive capacity , we suggest that the success of absorptive capacity processes requires a contingency approach for leadership to be adopted.

The present work further contributes by comparing two contrasting leadership styles, transformational and transactional. The findings of this study reveal that leaders can perform both transformational and transactional leadership styles in order to manage the learning processes of absorptive capacity effectively. We provided hard evidence of our findings by conducting a survey in a Middle Eastern country (UAE), which allowed us to generalise our findings beyond our research context. These findings can be a roadmap for managers wishing to manage the learning processes of absorptive capacity and benefit from external knowledge.

This study also has some limitations, which set the direction for future research. First, managers' ability to adopt transformational and transactional leadership styles differs (see Vera \& Crossan, 2004). Conducting a quantitative study prevents us from exploring the influence of factors such as managers' values, orientations and preferences on the effectiveness of transformational and transactional leadership styles in relation to absorptive capacity . Moreover, we did not explore the organisational conditions that influence the adoption of different leadership styles. We encourage future researchers to investigate organisational situations that affect the adoption of a transformational or a transactional leadership style. Finally, while we only investigated two types of leadership styles, we encourage future researchers to examine whether other leadership styles are also effective for managing the learning processes of absorptive capacity . 


\section{References}

Al-Waqfi, M. A. \& Forstenlechner, I. (2014). Barriers to Emiratization: The role of policy and design and institutional environment in determining the effectiveness of Emiratization. The International Journal of Human Resource Management, 24(2), 167-189.

Akoum, I. F. (2008). Conducting business in the UAE: a brief for international managers. Global Business and Organizational Excellence, 27(4), 51-66.

Aragón-Correa, J. A., García-Morales, V. J. and Cordón-Pozo, E. (2007). Leadership and organizational learning's role on innovation and performance: Lessons from Spain. Industrial Marketing Management, $36,349-359$.

Arbuckle, J.L., \& Wothke, W. (2003). Amos 5.0 User's Guide. Chicago, IL: SPSS Inc. and SmallWaters Corporation.

Avolio, B. J., Bass, B. M., \& Jung, D. I. (1999). Re-examining the components of transformational and transactional leadership using the Multifactor Leadership Questionnaire. Journal of Occupational and Organizational Psychology, 72, 441-462.

Barczak, G. and Wilemon, D. (1992). Successful new product team leaders. Industrial Marketing Management, 21, $61-68$.

Bass, B. M. (1985). Leadership and performance beyond expectations. New York: Free Press.

Bass, B. M. (1995). Transformational Leadership. Journal of Management Inquiry, 4(3), 293-298.

Bass, B. M. (1990). From transactional to transformational leadership: Learning to share the vision. Organizational dynamics, 18(3), 19-31.

Bass, B. M. (1999). Two decades of research and development in transformational leadership. European Journal of Work and Organizational Psychology, 8, 9-32.

Bass, B.M. and Avolio, B.J. (1995). MLQ: Multifactor Leadership Questionnaire, (2nd ed.). Redwood City, CA: Mind Garden.

Berson, Y., Nemanich, L. A., Waldman, D. A., Galvin, B. M. and Keller, R. T. (2006). Leadership and organizational learning: A multiple levels perspective. The Leadership Quarterly, 17(6), 577-594.

Bilgili, T. V., Kedia, B. L., \& Bilgili, H. (2016). Exploring the influence of resource environments on absorptive capacity development: The case of emerging market firms. Journal of World Business, 51(5), 700-712.

Boal, K. B., \& Hooijberg, R. (2001). Strategic leadership research: Moving on. The Leadership Quarterly, 11(4), 515-549.

Bollen, K. A. (1990). Overall fit in covariance structure models: Two types of sample size effects. Psychological Bulletin, 107(2), 256. 
Byrne, B. M. (2013). Structural equation modelling with AMOS: Basic concepts, applications, and programming. Routledge.

Cepeda-Carrion, G., Cegarra-Navarro, J. G. and Jimenez-Jimene, D. (2012). The effect of absorptive capacity on innovativeness: context and information systems capability as catalysts. British Journal of Management, 23(1), 110-129.

Cohen, W. M. and Levinthal, D. A. (1990). Absorptive capacity: a new perspective on learning and innovation. Administrative Science Quarterly, 35(1), 128-152.

Cohen, W. M., \& Levinthal, D. A. (1989). Innovation and learning: the two faces of R \& D. The Economic Journal, 99(397), 569-596.

Conger, J. A. (1999). Charismatic and transformational leadership in organizations: An insider's perspective on these developing streams of research. Leadership Quarterly. 10, 145-169.

Conger, J. A. and Kanungo, R. N. (1998). Charismatic leadership in organizations. Thousand Oaks, CA: Sage.

Crossan, M. M., Lane, H. W. and White, R. E. (1999). An organizational learning framework: From intuition to institution. Academy of Management Review, 24(3), 522-537.

Darwish, T. K., Zeng, J., Rezaei Zadeh, M., \& Haak-Saheem, W. (2018). Organizational Learning of Absorptive Capacity and Innovation: Does Leadership Matter?. European Management Review.

Dess, G. G. and Picken, J. C. (2000). Changing roles: Leadership in the 21 st century. Organizational Dynamics, 28(3), 18 - 34.

Eagly, A.H. (1992). Uneven progress: Social psychology and the study of attitudes. Journal of Personality \& Social Psychology, 63(5), 693-710

Easterby-Smith, M., Graça, M., Antonacopoulou, E. and Ferdinand, J. (2008). Absorptive capacity: A process perspective. Management Learning, 39(5), 483-501.

Elenkov, D. S., \& Manev, I. M. (2005). Top management leadership and influence on innovation: The role of sociocultural context. Journal of Management, 31(3), 381-402.

Flatten, T., Adams, D., \& Brettel, M. (2015). Fostering absorptive capacity through leadership: A crosscultural analysis. Journal of World Business, 50(3), 519-534.

Floh, A., \& Treiblmaier, H. (2006). What keeps the e-banking customer loyal? A multi group analysis of the moderating role of consumer characteristics on e-loyalty in the financial service industry. Journal of Electronic Commerce Research, 7 (2), 97-110.

Forstenlechner, I. \& Mellahi, K. (2011). Gaining Legitimacy through Hiring Local Workforce at a Premium: The Case of MNEs in the United Arab Emirates. Journal of World Business, 46(4), 455-461.

Forstenlechner, I. \& Rutledge, E. J. (2011). The GCC's 'Demographic imbalance: Perceptions, realities and policy options. Middle East Policy, 18(4), 25-43. 
García-Morales, V. J., Lloréns-Montes, F. J. and Verdú-Jover, A. J. (2008). The effects of transformational leadership on organizational performance through knowledge and innovation. British Journal of Management, 19(4), 299-319.

Gardner, W. L. and Avolio, B. A. (1998). The charismatic relationship: A dramaturgical perspective. Academy of Management Review, 23(1), 32-58.

Gebauer, H., Worch, H., \& Truffer, B. (2012). Absorptive capacity, learning processes and combinative capabilities as determinants of strategic innovation. European Management Journal, 30(1), 57-73.

Gumusluoğlu, L. and Ilsev, A. (2009). Transformational leadership and organisational innovation: The role of internal and external support for innovation. The Journal of Product Innovation Management, 26(3), 264-277.

Haak-Saheem, W., Darwish, T. K., \& Al-Nasser, A. D. (2016). HRM and knowledge-transfer: A micro analysis in a Middle Eastern emerging market. The International Journal of Human Resource Management, $1-30$.

Haak-Saheem, W., Festing, M., \& Darwish, T. K. (2017). International human resource management in the Arab Gulf States-an institutional perspective. The International Journal of Human Resource Management, 28(18), 2684-2712.

Haak-Saheem, W., Festing, M., \& Darwish, T. K. (2017). International human resource management in the Arab Gulf States-an institutional perspective. The International Journal of Human Resource Management, 28(18), 2684-2712.

Hair, J. F., Anderson, R. E., Tatham, R. L., \& William, C. Black (2006), Multivariate data analysis. International Edition, Prentice Hall: New Jersey.

Harry, W. (2007). Employment creation and localization: the crucial human resource issues for the GCC. The International Journal of Human Resource Management, 18(1), 132-146.

Hofstede, G. (1991). Cultural roots of economic performance: A research note. Strategic Management Journal, 12, 165-173.

Hoskisson, R. E., Wright, M., Filatotchev, I., \& Peng, M. W. (2013). Emerging multinationals from midrange economies: The influence of institutions and factor markets. Journal of Management Studies, 50(7), $1295-1321$.

Howell, J. M. and Avolio, B. J. (1993). Transformational leadership, transactional leadership, locus of control and support for innovation: Key predictors of consolidated-business-unit performance'. Journal of Applied Psychology, 78(6), 891-902.

Hu, L. T., \& Bentler, P. M. (1999). Cutoff criteria for fit indexes in covariance structure analysis: Conventional criteria versus new alternatives. Structural Equation Modelling: A Multidisciplinary Journal, 6(1), 1-55.

Hvidt, M. (2009). The Dubai model: An outline of key development-process elements in Dubai. International Journal of Middle East Studies, 41(03), 397-418.

Jane Zhao, Z., \& Anand, J. (2009). A multilevel perspective on knowledge transfer: evidence from the Chinese automotive industry. Strategic Management Journal, 30(9), 959-983. 
Jones, O. (2006). Developing absorptive capacity in mature organizations: The change agent's role, Management Learning, 37 (3), 355-376.

Jöreskog, K. (1973). A general method of estimating a linear structural equation system. In Goldberg, S.A. \& Duncan, D.O (Ed.), Structural Equations Models in Social Sciences (pp. 85 -112). New York, Seminar Press.

Jöreskog, K. G., \& Sörbom, D. (1989). LISREL 7: A guide to the program and applications (Vol. 2). Chicago: SPSS.

Jung, D. I. (2001). Transformational and transactional leadership and their effects on creativity in groups. Creativity Research Journal, 13(2), 185-195

Kapiszewski, A. (2006). Arab versus Asian migrant workers in the GCC countries. South Asian migration to Gulf countries: History, Policies, Development, 46-70.

Kim, C. S., \& Inkpen, A. C. (2005). Cross-border R\&D alliances, absorptive capacity and technology learning. Journal of International Management, 11(3), 313-329.

Lane, P. J., Koka, B. R. and Pathak, S. (2006). The reification of absorptive capacity: A critical review and rejuvenation of the construct. Academy of Management Review, 31(4), 833-863.

Lane, P. J., Koka, B. R., \& Pathak, S. (2006). The reification of absorptive capacity: A critical review and rejuvenation of the construct. Academy of Management Review, 31(4), 833-863.

Lane, P. J., Salk, J. E., \& Lyles, M. A. (2001). Absorptive capacity, learning, and performance in international joint ventures. Strategic Management Journal, 22(12), 1139-1161.

Lewin, A. Y., Massini, S., \& Peeters, C. (2011). Microfoundations of internal and external absorptive capacity routines. Organization Science, 22(1), 81-98.

Lichtenthaler, U. (2009). Absorptive capacity, environment turbulence, and the complementarity of organisational learning processes. Academy of Management Journal, 52(4), 822-846.

Lowe, K. B., Kroeck, K. G. and Sivasubramaniam, N. (1996). Effectiveness correlates of transformational and transactional leadership: A meta-analytic review. The Leadership Quarterly, 7(3), 385-425.

Malach-Pines, A., \& Kaspi-Baruch, O. (2008). The role of culture and gender in the choice of a career in management. Career Development International. 13(4), 306-319.

McGrath, R. G. (2001). Exploratory learning, innovative capacity, and managerial oversight. Academy of Management Journal, 44,118-131.

Mom, T. J. M., F. A. J. Van den Bosch, F. A. J. and Volberda, H. W. (2007). Investigating manager's exploration and exploitation activities: The influence of top-down, bottom-up, and horizontal knowledge inflows. Journal of Management Studies, 44 (6), 910-931.

Nonaka, I. and Takeuchi, H. (1995). The knowledge-creating company. New York: Oxford University Press.

Pablo, A. L., Reay, T., Dewald, J. R., and Casebeer, A. L. (2007). Identifying, Enabling and Managing Dynamic Capabilities in the Public sector. Journal of Management Studies, 44(5), 687-708. 
Podsakoff, P. M., S. B. Mackenzie and W. H. Bommer (1996). Transformational leader behaviors and substitutes for leadership determinants of employee satisfaction, commitment, trust and organizational citizenship behaviors. Journal of Management, 22, 259-298.

Rosing, K., Frese, M. and Bausch, A. (2011). Explaining the heterogeneity of the leadership-innovation relationship: Ambidextrous leadership. The Leadership Quarterly, 22(5), 956-974.

Senge, P., Roberts, C., Ross, R. B., Smith, B. J., and Kleiner, A. (1994).The fifth discipline fieldbook. New York: Doubleday.

Snell, R. S. (2001). Moral foundations of the learning organization. Human Relations, 54, 319 - 342.

Sun, P. Y. T. and Anderson, M. H. (2010). An examination of the relationship between absorptive capacity and organizational learning, and proposed integration. International Journal of Management Reviews, $12(2), 130-150$.

Sun, P. Y. T. and Anderson, M. H. (2012). The combined influence of top and middle management leadership styles on absorptive capacity. Management Learning, 43(1), 25-51.

Teece, D. J. (2007). Explicating dynamic capabilities: the nature and microfoundations of (sustainable) enterprise performance. Strategic Management Journal, 28(13), 1319-1350

Thorpe, M. \& Connell, J. (2013). Industry clusters, Dubai and the GCC: The antidote for growth and innovation after the GFC? Resources and Competitive Advantage in Clusters, 97

Todorova, G. and Durisin, B. (2007). Absorptive capacity: Valuing reconceptualization. The Academy of Management Review, 32(3), 774-786.

Todorova, G., \& Durisin, B. (2007). Absorptive capacity: Valuing a reconceptualization. Academy of Management Review, 32(3), 774-786.

Tsai, W. (2001). Knowledge transfer in intraorganizational networks: Effects of network position and absorptive capacity on business unit innovation and performance. Academy of Management Journal, 44(5), 996-1004.

Ulrich, D., M. A. Von Glinow and T. Jick (1993). High-impact learning: building and diffusing learning capability. Organizational Dynamics, 22(2), 52-66.

Vera, D. and Crossan, M. (2004). Strategic leadership and organizational learning. Academy of Management Review, 29, 222-240.

Volberda, H. W., Foss, N. J. and Lyles, M. A. (2010). Absorbing the concept of absorptive capacity: How to realize its potential in the organization field. Organization Science, 21(4), 931-951.

World Bank Group (Ed.). (2012). World Development Indicators 2012. World Bank Publications.

Yammarino, F. J., Spangler, W. D., \& Bass, B. M. (1993). Transformational leadership and performance: A longitudinal investigation. The Leadership Quarterly, 4(1), 81-102.

Yukl, G. (1999). An evaluation of conceptual weaknesses in transformational and charismatic leadership theories. The Leadership Quarterly, 10, 285-305.

Zahra, S. A. and George, G. (2002). Absorptive capacity: A review, reconceptualization, and extension. Academy of Management Review, 27(2), 185-203. 
INSERT APPENDIX A HERE 